Saint Louis University School of Law

Scholarship Commons

All Faculty Scholarship

2002

\title{
Whither Antitrust? The Uncertain Future of Competition Law in Health Care
}

Thomas L. Greaney

Saint Louis University School of Law

Follow this and additional works at: https://scholarship.law.slu.edu/faculty

Part of the Antitrust and Trade Regulation Commons, and the Health Law and Policy Commons

Recommended Citation

Greaney, Thomas L., Whither Antitrust? The Uncertain Future of Competition Law in Health Care. Health Affairs.

This Abstract is brought to you for free and open access by Scholarship Commons. It has been accepted for inclusion in All Faculty Scholarship by an authorized administrator of Scholarship Commons. For more information, please contact erika.cohn@slu.edu, ingah.daviscrawford@slu.edu. 


\title{
Whither Antitrust? The Uncertain Future of Competition Law in Health Care
}

Health Affairs

Thomas L. Greaney

Saint Louis University - School of Law

Date Written: June 3, 2002

\begin{abstract}
$\underline{\text { Abstract }}$
Although instrumental in ushering in competition to the health care industry and later in safeguarding the competitive structure of markets, antitrust law has come under attack. A series of questionable judicial decisions has clouded the standards applicable to analyzing health care markets. Legislative efforts to immunize conduct from antitrust challenge also have gathered support in recent years. This study finds scant economic or policy basis for these developments and concludes that anti-managed sentiments have diluted enthusiasm for applying competitive principles in health care. This phenomenon has resulted in outcome-driven judicial decisions and legislative activity geared to serving political expediency rather than sound policy tenets. The paper recommends heightened antitrust scrutiny of provider and insurer markets by federal and state enforcers and increased empirical research into the workings of imperfect health care markets and the effects of past antitrust decisions.
\end{abstract}

\section{Suggested Citation:}

Greaney, Thomas L., Whither Antitrust? The Uncertain Future of Competition Law in Health Care. Health Affairs. 